\title{
ESTUDO DE CASO: VERIFICAÇÃO DO USO DE EMBALAGENS DESCARTÁVEIS E RETORNÁVEIS NA CADEIA LOGÍSTICA DE PEÇAS AUTOMOTIVAS
}

\author{
Hugo Flávio dos Santos, MsC. (ICE-FIAT) \\ Orientador: Paulo Cesar Machado Ferroli, Dr. Eng. (UFSC)
}

\section{INTRODUÇÃO}

O presente estudo trata o tema: logística reversa e sua utilização em um estudo focado nas embalagens retornáveis e recicláveis tendo como base de aplicação a região metropolitana de Belo Horizonte - MG. O objetivo da pesquisa foi proporcionar a análise do impacto ambiental dos meios de acondicionamento de peças automotivas visando a comparação econômica e ambiental das referidas embalagens em um fluxo de logística reversa. A proposta do estudo foi baseada na questão do retorno de embalagens que são reutilizadas no envio de peças para um determinado grupo de concessionárias de veículos. Esse retorno é baseado no conceito da logística reversa, que garante no geral a devida destinação dos resíduos após o fim do ciclo das embalagens. Como metodologia da pesquisa, utilizou-se da pesquisa hipotético-dedutiva e quanto aos fins utilizou-se a pesquisa aplicada. O desenvolvimento da pesquisa contou ainda com a busca por informações técnicas das embalagens e da rota a ser aplicada à logística reversa, e com base nestas informações elaborou-se quadros e tabelas contendo informações de custos e viabilidade de cada um dos pontos em observação. Pelo estudo realizado, chegou-se a conclusão que a utilização de uma embalagem de papelão com maior ciclo de utilização é economicamente mais viável, da mesma forma que ambientalmente a redução na emissão de resíduos faz desta uma embalagem que favorece mais à sustentabilidade do processo.

\section{APLICAÇÃO - ESTUDO DE CASO}

O conceito da logística reversa é complementado pelo do ciclo de utilização. Isso porque o tempo útil de um produto, do ponto de vista logístico, não termina apenas com a entrega do cliente. Por algum motivo os produtos tendem a retornar ao seu destino, seja por obsolescência, dano, avaria, ou qualquer outro motivo que os levem a retornar ao ponto de origem.

A logística reversa vai muito além da necessidade de reenvio de um produto, mas, envolve também o ponto de origem de todo o processo e o destino, com objetivo de interligar cada ponto e gerar o maior número de dados possíveis. A figura 1 demonstra o esquema de atividades que envolvem o processo de logística reversa.

Para que haja a utilização plena da logística reverFigura 1: Atividades típicas do processo logístico reverso.

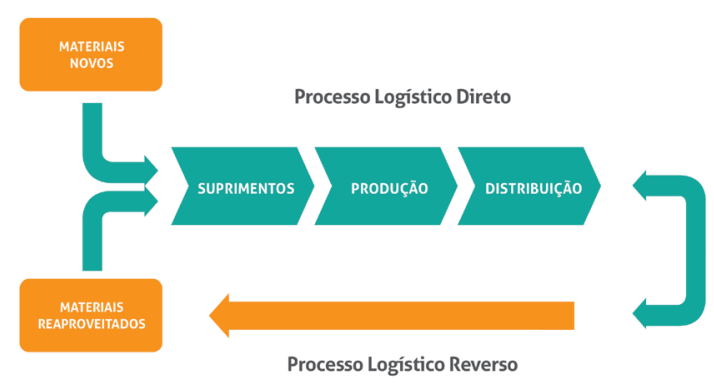

sa é necessário determinar os fatores que são inerentes ao processo. A duração de um produto, sob o ponto de vista logístico, pode ir muito além que sua simples entrega ao 
consumidor final. Por diversos motivos, produtos podem retornar ao ponto de origem, como por exemplo, obsolescência, dano ou avaria, recusa na aquisição, enfim, alguns motivos como apresentados promovem o retorno do produto ao seu ponto de origem devendo estes ser descartados, reparados ou reaproveitados de forma correta e criteriosa.

No trabalho em questão a utilização de embalagens para transporte dos produtos pode ser constituída a partir de diversos produtos, sendo estes relacionados no quadro 1

Quadro 1 - Ciclo de vida de embalagens utilizadas na logística reversa

\begin{tabular}{|c|c|}
\hline Material & Ciclo \\
\hline Papelão reciclado & 1 \\
\hline Papelão ondulado BC Kraf & 6 \\
\hline Papelão ondulado Triwal Kraft & 80 \\
\hline Polionda & 200 \\
\hline Madeira & 250 \\
\hline
\end{tabular}

Após aplicação prática na empresa, destacam-se, no quadro 2 os aspectos relevantes.

Quadro 2 - aspectos relevantes.

\begin{tabular}{|c|c|}
\hline Aplicação & Aspectos Relevantes \\
\hline Vantagens econômicas & $\begin{array}{c}\text { Papelão Triwall Kraft: } \\
\text { proporciona como redu- } \\
\text { ção de custos: danos aos } \\
\text { produtos transportados, } \\
\text { devido ao melhor acondi- } \\
\text { cionamento e redução de } \\
\text { espaço interno de armaze- } \\
\text { nagem em função do ciclo } \\
\text { durável das embalagens }\end{array}$ \\
\hline
\end{tabular}

Vantagens logísticas

Redução na complexidade da operação a partir dos seguintes pontos: aproveitamento de um fluxo de retorno já existente antes não utilizado; melhores indicadores quantitativos quanto à avarias devido ao melhor acondicionamento da embalagem retornável; e possibilidade de meIhor aproveitamento de cubagem em função da padronização das embalagens.

\begin{tabular}{|c|c|}
\hline & lagens. \\
\hline \multirow[t]{2}{*}{ Vantagens ecológicas } & $\begin{array}{l}\text { Destinação correta dos } \\
\text { resíduos de papelão com } \\
\text { tratamento específico e } \\
\text { adequado pela empresa } \\
\text { que faz a logística de } \\
\text { distribuição; aplicação } \\
\text { da logística reversa sem } \\
\text { aumento de km nem do } \\
\text { tipo de veículo utilizado; } \\
\text { menor índice de peças } \\
\text { descartadas ao meio am- } \\
\text { biente devido ao }\end{array}$ \\
\hline & $\begin{array}{l}\text { melhor acondicionamento } \\
\text { da embalagem retornável; } \\
\text { e redução da quantidade } \\
\text { de papelão descartado em } \\
\text { função do ciclo da emba- } \\
\text { lagem utilizada. }\end{array}$ \\
\hline Vantagens sociais & $\begin{array}{l}\text { Com este fluxo, mesmo re- } \\
\text { duzindo custos a empresa } \\
\text { gera mais empregos nos } \\
\text { seguintes pontos: con- } \\
\text { trole e gestão de embala- } \\
\text { gens; e controle e gestão } \\
\text { de resíduos; }\end{array}$ \\
\hline
\end{tabular}




\begin{tabular}{|c|c|}
\hline Desvantagens custo & $\begin{array}{c}\text { Criação da necessidade } \\
\text { de espaço físico para } \\
\text { acondicionamento das } \\
\text { embalagens de retorno no } \\
\text { destino final; e necessida- } \\
\text { de de desenvolvimento de } \\
\text { sistemas de gestão. }\end{array}$ \\
\hline Desvantagem logística & $\begin{array}{c}\text { Rigidez no transporte em } \\
\text { função da necessidade de } \\
\text { retorno }\end{array}$ \\
\hline Desvantagem financeira & $\begin{array}{c}\text { Necessidade de investi- } \\
\text { mento inicial elevado em } \\
\text { embalagens retornáveis }\end{array}$ \\
\hline
\end{tabular}

\section{CONCLUSÕES}

A análise das embalagens pode ser divida em duas partes. A primeira, sob o ponto de vista teórico que demonstrou que as embalagens retornáveis são viáveis por reduzir desperdícios de embalagens e de produtos transportados, por serem melhores acondicionados. Por outro lado, deve-se considerar que estas possuem pontos negativos como a geração de custos de transporte direto e transporte de retorno, demandando controle de fluxo, recepção, reparos, capital ativado entre outros. A segunda parte foi a aplicação prática, onde estruturou-se rotas menores e se comparou o uso de embalagens descartáveis com as retornáveis. Esta comparação levou em conta o maior número possível de variáveis de custo e logística, sendo que, as embalagens descartáveis foram mais onerosas, com maior volume de rejeito anualmente. As embalagens retornáveis promoveram a otimização do transporte. Além disso, elas melhoraram a qualidade do transporte dos produtos, por acondicionarem estes de forma mais adequada. O ciclo de vida da embalagem de Papelão ondulado Triwall Kraft promoveu uma redução significativa na emissão de resíduos, além de ser a embalagem escolhida para aplicação no fluxo por ser aquela de menor custo.

O estudo evidenciou o quantitativo por tipo de embalagem focando na emissão de resíduos. No entanto, não foi possível aprofundar no objetivo de demonstrar como cada tipo de material utilizado nas embalagens consegue evitar certos danos ao meio ambiente, devido principalmente, à forma como a pesquisa foi conduzida, estando muito ligada às características dos materiais e sua viabilidade de aplicação na logística reversa.

Finalmente, chegou-se a conclusão que a utilização da embalagem de Papelão Ondulado Triwall Kraft é a mais viável por fatores como seu ciclo de vida, o acondicionamento ideal dos produtos, seu manuseio, o custo benefício em geral, tornando-a economicamente mais barata. Ambientalmente proporcionou à empresa a redução na emissão de resíduos em consequência do maior volume de uso nos ciclos. 